INTERNATIONAL JOURNAL OF RESEARCH IN PHARMACY AND CHEMISTRY

Available online at www.ijrpc.com

Review Article

DOI: https://dx.doi.org/10.33289/IJRPC.9.4.2019.980

\title{
OVER VIEW OF TRADITIONAL HERBAL REMEDIES FOR PRIMARY HEALTH CARE
}

\author{
U. Abhinaya and G. Uma Rani ${ }^{\star}$ \\ RBVRR women's College of Pharmacy, Hyderabad, Telangana, India.
}

\begin{abstract}
Because of individual cultural and historical influences traditional systems of medicines are being part of health care by people in various countries. Herbal medicines are plant derived materials and preparations with therapeutic or other human health benefits, which contain either raw or processed ingredients from one or more plants, inorganic materials or animal origin. The WHO defines herb as being fresh or dried, fragmented or powdered plant material which can be used in crude state. Herbs can be prepared by squeezing, steaming, roasting, decocting or infusing in water. This review explains the few herbal ingredients and their method of preparation for treating common ailments in day to day life.
\end{abstract}

Keywords: Herbal drugs, Decoction, Chemical composition, Health care.

\section{INTRODUCTION}

Herbal medicine constitutes the main component of traditional medicine, which have been used since thousands of years. They have made significant contribution to human health through their promotive, curative properties and in the prevention of illness. At present the use of herbal medicines are increasing worldwide. They can be prepared easily and used for primary health care. It is also increase availability and accessibility to cost effective treatment of commonly encountered health problems with herbal remedies. In this review mentioned the form of traditional preparation and its composition, latin name, english name, family of the plant, plant part used, chemical constituents, method of preparation, dosage form, standards, therapeutic properties, precautions etc.

\section{Treatment of Common cold}

\section{Trikatu powder}

Trikatu powder is a simple formulation made by mixing fine powders of three commonly used herbal drugs in equal quantity namely dry ginger (shunthi) black pepper (maricha), and long pepper (pippali). All the three ingredients are predominantly of pungent taste. All the three are spices used commonly in the kitchen and traded widely from india since ancient times. ${ }^{1}$

\begin{tabular}{|c|c|c|c|c|c|}
\multicolumn{1}{|c|}{ Composition } \\
\hline Name & English name & Latin name & Family & Part used & Chemical constituents \\
\hline Shunthi & Dry ginger & Zingiber officinale rose & Zingiberaceae & Rhizome & $\begin{array}{c}\text { Essential oils, pungent constituents } \\
\text { (gingerol and shogaol), resinous } \\
\text { matter and starch }\end{array}$ \\
\hline Maricha & Black pepper & Piper nigrumlinn. & Piperaceae & Fruit & $\begin{array}{c}\text { Alkaloids(piperine, piperidine, } \\
\text { piplartin), essential oils }\end{array}$ \\
\hline Pippali & Long pepper & Piper longumlinn. & piperaceae & Fruit & $\begin{array}{c}\text { Alkaloid (piperine, } \\
\text { piplartine,sesamin), essential oil }\end{array}$ \\
\hline
\end{tabular}

\section{Method of preparation}

Take 50gms of eachof the three ingredients, dry them further to remove the moisture for easy powdering. Take an equal quantity of each drug of trikatu and mixwell in a dry container. Grind the 
mixture in a grinder or pulverizer till fine powder is obtained. Sieve the powder through 85 mesh to remove the coarse fibers and other particles.

Keep trikatu powder in an air-tight dry container of glass or food grade plastic; store in a dry cool place away from direct sunlight. It is good to use powder within one year.

\section{Dosage form}

Blackish brown fine powder.

\section{Therapeutic properties}

anti-inflammatory, analgesic, expectorant, digestive, carminative.

\section{Dose and mode of administration}

Adult dose of trikatu is 2 gms given 3 times a day preferably with warm water or milk or honey in children the dose may be reduced according to age can be given in dose of $125 \mathrm{mg}-500 \mathrm{mg}$ thrice a day ${ }^{1}$.

\section{For the treatment of cough}

Pippali powder: pippali powder is s single ingredient herbal formulation made from the fruits of long pepper, an aromatic climber with perennial woody roots.

\section{composition}

Pippali powder is made from dried fruits of piper longum. ${ }^{2}$

\begin{tabular}{|c|c|c|c|c|}
\hline English name & latin name & family & part used & Chemical constituents \\
\hline Long pepper & Piper longumlinn & piperaceae & Fruits & $\begin{array}{c}\text { Essential oil and alkaloids } \\
\text { (piperine, sesamine, piplartine) }\end{array}$ \\
\hline
\end{tabular}

\section{Method of preparation}

Dried long pepperfruits are cleaned and powdered in a grinder or mortar. Powder is sieved through mesh of 85 size and kept in an air tight plastic or glass container. Exposure to moisture should be avoided. It is advisable to prepare atleast $50 \mathrm{gms}$ of powder at a time ${ }^{2}$

\section{Dosage form}

Blackish green powder with aromatic odour and pungent taste.

\section{Therapeutic properties}

Pippali powder has anti- inflammatory anti-phlegmatic, decongestant, anti-spasmodic, anti-allergic, expectorant anthelmintic, immune stimulatory and tonic properties ${ }^{2}$

\section{Dose and mode of administration}

The adult dose of the formulation is $1-3 \mathrm{gms}$ and the children's dose is $125 \mathrm{mg}-250 \mathrm{mg} 2$ or 3 times a day, mixed with honey or warm water ${ }^{2}$

\section{For the relief of fever}

Kiratatikta powder: it consist of dried, matured pieces of whole plant of swertiachirata annual, herbaceous plant ${ }^{3}$

\section{Composition}

The formulation is a powder made from dried, maturedpieces of whole plant of swertiachirata. ${ }^{3}$

\begin{tabular}{|c|c|c|c|c|}
\hline English name & Latin name & Family & Part used & Chemical constituents \\
\hline Chiretta,chirata & Swertiachirata & gentianaceae & Whole plant & Xanthones, xanthone glycoside and flavonoid \\
\hline
\end{tabular}

\section{Method of preparation}

Take dried whole plant of kiratatitka and further dry it In the shade to remove moisture for easy powdering or making coarse powder for decotion. grind the material in a grinder or pulverizer until the fine powder or coarse powder is obtained. For obtaining then fine powder filter it through mesh size 85 coarse powder is used as such for decotion, there is no need to filter it. The shelf of the powder is 4 months. Stored in an air tight container and protected from direct sunlight and heat. ${ }^{(3)}$ 


\section{Dosage form}

Dark brownish bitter powder or, dark brownish bitter liquid.

\section{Therapeutic properties}

Anti-pyretic, anti- malarial, anti helmentic, anti- tubercular, anti- inflammatory, anti diabetic, laxative, stomachic, tonic ${ }^{3}$.

\section{Dose and mode of action}

For adult is $1-3 \mathrm{gms}$ and children it is $250 \mathrm{mg}-500 \mathrm{mg}$ with water.the dose of decotion for adults is $25-30$ $\mathrm{ml}$ and for children, it is $5 \mathrm{ml}-10 \mathrm{ml}$ to be taken twice a day after meals ${ }^{3}$.

Headache

Pippalimoola powder

Composition

\begin{tabular}{|c|c|c|c|c|}
\hline English name & Latin name & Family & Part used & Chemical constituents \\
\hline Long pepper & Piper longumlinn. & Piperaceae & fruit & $\begin{array}{c}\text { Alkaloids(piperine, piperlongumine, } \\
\text { piperlonguminine), essential oils }\end{array}$ \\
\hline
\end{tabular}

\section{Method of preparation}

Take 40gms of dried roots of pippali. Dry it further for removing moisturefor easy powdering. Roots should not have been collected more than one year ego. Grind the roots ina grinderor pulverizer till the fine powderis obtained. Filter the powder through mesh size 85. Keep the powder in a dry and air tight plasticor glass container. ${ }^{4}$

\section{Dosage form}

reddish brown to creamy grey bitter powder.

\section{Therapeutic properties}

The roots of pippali have thermogenic, tonic, diuretic, purgative, expectorant, anthelmintic, stomachic, digestive, anti-bacterial, anti-inflammatory, CNS stimulant, analeptic properties. ${ }^{4}$

\section{Dose and mode of administration}

Dose of the powder for adults is $2-3 \mathrm{gms}$ and for children it is $250-500 \mathrm{mg}$ to be taken twice daily, preferably on an empty stomach mixed with $3-5 \mathrm{gms}$ of ghee or butter or honey and followed by warm water or milk ${ }^{4}$

\section{Indigestion}

\section{Chaturbhadra decotion}

Composition

Chaturbhadra decotion is made from the following four ingredients in equal parts ${ }^{5}$

\begin{tabular}{|c|c|c|c|c|c|}
\hline $\begin{array}{c}\text { Name of the } \\
\text { drug }\end{array}$ & English name & Latin name & Family & Part used & Chemical composition \\
\hline Ativisha & Indian atis & $\begin{array}{c}\text { Aconitum } \\
\text { heterophyllum }\end{array}$ & Ranunculaceae & Root & $\begin{array}{c}\text { Alkaloids(atisine, dihydroatisine, } \\
\text { hetisine, }\end{array}$ \\
\hline Guduchi & Tinospora & Tinosporacordifolia & menispermaceae & Stem & Terpenoids, alkaloids \\
\hline Mustaka & Nut grass & Cyperusrotunduslinn & Cyperaceae & Rhizome & Volatile oil \\
\hline shunthi & Ginger & Zingiberofficinale & Zingiberaceae & rhizome & $\begin{array}{c}\text { Essential oil, pungent } \\
\text { constituents(gingerols, } \\
\text { shogaols) resinous matter and } \\
\text { starch }\end{array}$ \\
\hline
\end{tabular}

\section{Method of preparation}

First dry and clean all the four ingredients. Make coarse powder of each ingredient. Take the coarse powder of all the four drugs in equal quantity and mix properly. The mixture should be stored in an air tight container for use within one year, after which it potency is reduced. Boil $10 \mathrm{gms}$ of the mixture in $160 \mathrm{ml}$ of water till one fourth water remains. Filter the liquid .add 1-2gms of fine powder of ginger and cumin seeds in the decotion just before taking, to make it more effective. ${ }^{5}$

\section{Dosage form}

Warm light brownish decoction 


\section{Dose and administration}

The dose for adults is $40 \mathrm{ml}$ of freshly prepared warm decotion and $5-10 \mathrm{ml}$ for children, to be administered twice a day before meals. It is advisable to sip the decotion instead of swallowing it in one lot. ${ }^{5}$

For acidity and gastritis

Amalakipowder

\section{Composition}

The formulation is a fine powder made of single herbal ingredient amalaka

\begin{tabular}{|c|c|c|c|c|}
\hline English name & Latin name & Family & Part used & Chemical constituents \\
\hline Indian gooseberry & Phyllanthusemblica & Phyllanthaceae & Fruit & Vitamin-c, minerals and amino acids \\
\hline
\end{tabular}

\section{Method of preparation}

Seedless dried fruits of amalaka are cleaned and ground into finepowder using a grinder or pulverizer. Powder is sieved through mesh to remove coarse particles and fibers. The powder should be kept in a dry air tight container to prevent exposure to moisture. Potency of the properly preserved dried fruits lasts for one year ${ }^{9}$.

\section{Dosage form}

Fine, sour tasting grayish to blackish powder ${ }^{9}$.

\section{Therapeutic properties}

Antacids, anti-ulcer, anti-emetic, anti-inflammatory, antioxidant, immunomodulator, rejuvenator, rich source of vitamin C.

\section{Dose and administration}

In adults, the dose is $3-6 \mathrm{gms}$ and in children $500 \mathrm{mg}-1 \mathrm{gm}$,twice a day, to be swallowed on an empty stomach or just before meals with water ${ }^{9}$.

\section{For Constipation \\ Haritaki powder \\ Composition}

Haritaki powder is fine powder of dried ripe fruits of terminaliachebula ${ }^{7}$

\begin{tabular}{|c|c|c|c|c|}
\hline English name & Latin name & Family & Part used & Chemical constituents \\
\hline Chebulic myrobalan & Terminalia chebula & combretaceae & Dried fruits without seeds & $\begin{array}{c}\text { Anthraquinone, glycoside, } \\
\text { chebulinicacid,chebulagic acid }\end{array}$ \\
\hline
\end{tabular}

\section{Method of preparation}

Take dried fruits of haritaki, remove their seeds and dry them further in the shade avoiding direct sunlight. Fruits should not have been harvested more than six months ago. Make fine powder in a grinder or pulverizer. Sieve the powder through 85 size mesh to remove coarse fibers and other particles. Keep the powder in a dry and air-tight plastic or glass container and consume it within six months or before the next rainly season, whichever is earlier'.

\section{Dosage form}

brownish fine powder

\section{Therapeutic properties}

Haritaki has laxative, carminative, digestive, antispasmodic, anthelmintic, anti-microbial, anti-stress ${ }^{(7)}$

\section{Dose and mode of action}

Adult dose of powder is 3-6gms and for children, the dose of haritaki is $500 \mathrm{mg}-1 \mathrm{gm}$, to be taken with luke warm water once a day on empty stomach. it is preferably taken early in the morning or minimum three hours after dinner.

\section{Vomiting}




\section{Ela powder}

Ela powder consists of finely powdered seeds of dried fruits of cardamom ${ }^{10}$.

\section{Composition}

\begin{tabular}{|c|c|c|c|c|}
\hline English name & Latin name & Family & Part used & Chemical constituent \\
\hline Cardomom & Elettariacardamomum & Zingiberaceae & Seeds & Essential oils(terpineol, myrcene ) \\
\hline
\end{tabular}

\section{Method of preparation}

Skin of the fruits before grinding the seeds to make powder. About $10 \mathrm{gms}$ of seeds are sufficient for a treatment period of 7-10days. Grind the seeds in a clean grinder or mortar to make a fine powdered filter it through a metallic sieve. Seed powder is then kept in a dry air tight small bottle, away from direct sunlight and heat ${ }^{10}$.

\section{Dosage forms}

Brownish powder with strongly aromatic odour and characteristic taste. The powder can filled into capsules ${ }^{10}$.

\section{Therapeutic properties}

Cooling, anti-emetic, stimulant, carminative, digestive, stomachic and appetizing properties antiinflammatory, anti-spasmodic, anti- microbial and anti-fungal properties ${ }^{(10)}$

\section{Dose and mode of indication}

Seed powder of ela is recommended in dose of $250 \mathrm{mg}$ to $500 \mathrm{mg}$ for adults and $60-120 \mathrm{mg}$ for children 2-3 times a day with a little warm water or honey. It is advisable to consume the powder on an empty stomach or half an hour before meals ${ }^{10}$.

Wound

Haridra powder

\section{Composition}

Haridra powder is a made of a single herbal ingredient haridra

\begin{tabular}{|c|c|c|c|c|}
\hline English name & Latin name & Family & Part used & Chemical constituents \\
\hline turmeric & curcuma longa linn. & zingiberaceae & rhizome & curcuminoids, curcumin and essential oils \\
\hline
\end{tabular}

\section{Method of preparation}

Powder of turmeric is prepared by grinding dried rhizomes in a grinder or pulverizer and then sieve through mesh size 80 . The powder should kept in a clean container and stored in a dry area away from sunlight. decotion of turmeric for washing wounds is made by boiling $10 \mathrm{gms}$ of powder in $200 \mathrm{ml}$ of water till one fourth liquid remains. paste for application over the wound is prepared by mixing 5$10 \mathrm{gms}$ of turmeric powder in an equal amount of clean water. ${ }^{8}$

\section{Dosage form}

yellow- coloured powder, decotion and paste.

\section{Therapeutic properties}

Haridra has anti-inflammatory, blood purifying, anti-allergic, anti-bacterial, anti-fungal, anti-protozoal and wound healing properties.

\section{Dose and mode of administartion}

For oral use the dose of turmeric powder for adults is $2-5 \mathrm{gms}$ and for children it is 1-2gms or juice of fresh turmeric in the dose of $10-20 \mathrm{ml}$ for adults and $5-10 \mathrm{ml}$ for children. It is administered daily twice with water or honey. Wash the wound twice daily with turmeric decotion .apply the thin paste of turmeric over the wound and keep it for 8-10hrs and then remove by gently washing the affected part with luke warm water ${ }^{(8)}$

Tooth ache

Lavangaoil

Composition

Lavanga oil is extracted from the buds of clove ${ }^{11}$

\begin{tabular}{|l|l|l|l|l|}
\hline English name & Latin name & Family & Parts used & Chemical constituents \\
\hline
\end{tabular}




\begin{tabular}{l|l|l|l|l} 
Clove & Syzigiumaromaticumlinn & Myrtaceae & Flower buds & Eugenol, eugenol acetate and caryophyllene \\
\hline
\end{tabular}

\section{Method of preparation}

Clove oil Is usually available in grocery and medical shops. It is prepared by water distillation of clove buds containing the desired percentage of eugenol ${ }^{11}$.

\section{Dosage form}

Clove oil has a warm, strong, spicy smell and the oil is colourless to pale yellow with a medium to watery viscosity ${ }^{11}$.

\section{Therapeutic properties}

Clove oil is analgesic, anaesthetic, antiseptic, digestive, refrigerant, carminative, stomachic, antispasmodic and rubefacient ${ }^{11}$.

\section{Dose and mode of action}

Cotton swab soaked in clove oil should be kept on the affected tooth without touching the gums .gargles with 1-2drops of clove oil in a cup of warm water are useful as a mouth wash for toothache and gum problems ${ }^{11}$.

\section{Urinary disorder \\ Gokshurapowder}

\section{Composition}

The powder and decotion of gokshura are made from dried ripe fruits or the entire plant ${ }^{15}$

\begin{tabular}{|c|c|c|c|c|}
\hline English name & Latin name & Family & Part used & Chemical constituents \\
\hline $\begin{array}{c}\text { Land caltrops, puncture } \\
\text { wine }\end{array}$ & Tribulusterrestrislinn. & zygophyllaceae & Fruits and whole plant & $\begin{array}{c}\text { Potassium nitrate, sterols, } \\
\text { sapogenin, } \\
\text { diosgenin,chlorogenin }\end{array}$ \\
\hline
\end{tabular}

\section{Method of preparation}

Depending upon the durationof treatment take $50-100 \mathrm{gms}$ of dried fruits or whole plants harvested not more than one year before. The raw material should bedried further by keeping it in sunlight or in drier. Make fine powder in grinder and filterit through a 85 mesh sieve to remove coarse woody particles and fibers. Keep the powder in an air tight glass container away from moist surroundings. Decotion of gokshura is prepared by boiling $20-30 \mathrm{gms}$ of the coarse powder of the raw materials in $160-240 \mathrm{ml}$ water till one fourth liquid remains. Decotion has to be prepared daily and consume fresh same day ${ }^{15}$.

\section{Dose}

Fine, pale -coloured powder and straw coloured decotion ${ }^{15}$.

\section{Therapeutic properties}

It has cooling, diuretic, anti-urolithiatic, styptic, antimicrobial, musle relaxant, emollient, antiinflammatory and cyto protective properties ${ }^{15}$.

\section{Dose and administration}

The adult dose is 3-6 gms, twice a day with water before meals. the dose of decotion for adult is 40 $50 \mathrm{ml}$ and it should be taken luke warm ${ }^{15}$.

\section{Sprain}

\section{Haridrapowder}

\section{Composition}

Haridra powder made from rhizomes is used orally as well as for local application ${ }^{(12)}$

\begin{tabular}{|c|c|c|c|c|}
\hline English name & Latin name & Family & Parts used & Chemical constituents \\
\hline Turmeric & Curcuma longa. linn & zingiberaceae & rhizome & $\begin{array}{c}\text { Curcumin, essential oil with high content of } \\
\text { bisabolane derivatives }\end{array}$ \\
\hline
\end{tabular}

\section{Method of preparation}

Take 50gms of dried rhizomes of haridra and dry them further to remove moisture for easy powdering .rhizomes should have been harvested not more than one year ago. Grind rhizome in grinder till fine 
powder is obtained. Filter the powder through 85 mesh sieve to remove coarse fibers and other particles. Keep the powder in a dry and air-tight glass or plastic container away from sunlight ${ }^{12}$.

\section{Dosage form}

Dusty, yellow-coloured fine powder ${ }^{12}$

\section{Therapeutic properties}

Turmeric powder has anti-bacterial, insecticidal, anti-inflammatory and anti-arthritic properties ${ }^{(12)}$

\section{Dose and mode of administration}

For oral use, the dose of turmeric powder for adult is $2-5 \mathrm{gms}$ and for children $1-2 \mathrm{gms}$. the dose of fresh turmeric juice is $10-20 \mathrm{mls}$ in adults and $5-10 \mathrm{ml}$ in children. normally two doses a day should be taken with water or mixed with honey. a paste made from rhizomes, mixed with lime and salt, is applied to the sprained area and removed when it gets dried ${ }^{12}$

\section{Sexual dysfunction}

Kapikacchu powder

Composition

kapikacchu powder consist of powdered seeds of mucunapuriens ${ }^{14}$

\begin{tabular}{|c|c|c|c|c|}
\hline English name & Latin name & Family & Part used & Chemical constituents \\
\hline Cow hedge & Mucunaprurines & Fabaceae & seeds & $\begin{array}{c}\text { It is a good source of L-dopa and } \\
\text { number of essential oils }\end{array}$ \\
\hline
\end{tabular}

\section{Method of preparation}

Clean the dried seeds of kapikacchu by removing dust and other foreign materials and grind them into a fine powder. filter the powder through85 mesh sieve and store in an air tight or plastic food container, away from direct sunlight and in a cool place. the potency of kapikacchu powder is best retained upto 4 months after preparation ${ }^{14}$

\section{Dosage form}

Light-brownish powder ${ }^{14}$

\section{Therapeutic properties}

kapikacchu powder has aphrodisiac, nervine tonic, anti-parkinsonism, anti-inflammatory, and hypo cholesterolaemic properties ${ }^{14}$

\section{Dose and mode of administration}

seed powder in the dose of $3-5 \mathrm{gms}$ once a day with warm milk at night ${ }^{14}$

\section{Painful menstruation \\ Shatpushpa powder}

\section{Composition}

The formulation consists of powdered dry fruits of shatpushpa ${ }^{16}$

\begin{tabular}{|c|c|c|c|c|}
\hline English name & Latin name & Family & Part used & Chemical constituents \\
\hline Dill & Anethumsowaroxb.ex & apiaceae & Dried ripe fruits & $\begin{array}{c}\text { Essential oils, aromatic glycosides, } \\
\text { monoterpenoid, ketodiols }\end{array}$ \\
\hline
\end{tabular}

\section{Method of preparation}

Clean shatpushpa dried fruits by removing dust and other foreign particles .grind fruits in a dry grinder or pulverizer. Filter the powder through sieve with mesh size 85 . Store the powder in an air tight, glass or food grade plastic container and store in a dry and cool place away from direct sun light

Soft decotion or infusion is prepared by boiling $2-3 \mathrm{gms}$ of shatpushpa in $150 \mathrm{ml}$ of water until half of it remains. or soak shatpushpa fruits in $25-30 \mathrm{ml}$ of hot water for half an hour and then filter the contents to obtain infusion ${ }^{16}$

\section{Dosage form}

Brownish powder and decotion is light brown liquid ${ }^{16}$.

\section{Therapeutic propeties}

The preparation has anti-spasmodic, stomachic, carminative, anti-flatulent, and emmenagogue properties $^{16}$. 


\section{Dose and mode of administration}

2-3gms of the powder is to be taken twice a day with warm water, preferably after meals. the powder can be mixed with an equal amount of honey and swallowed with warm water or milk or, $25-30 \mathrm{ml}$ of decotion or infusion can be taken twice or thrice daily . forcontinous pain and heaviness use of 2-3 tea spoonful infusion is recommended at hourly intervals ${ }^{16}$.

\section{Leaucorrhoea \\ Lodhrapowder \\ Composition}

The formulation consist of finely powdered stem bark of symplocos tree ${ }^{13}$.

\begin{tabular}{|c|c|c|c|c|}
\hline English name & Latin name & Family & Part used & Chemical constituents \\
\hline Symplocos bark & Symplocosnracemosaroxb. & symplocacea & Dried stem bark & $\begin{array}{c}\text { Alkalaoids(loturine, loturidine, } \\
\text { colloturine and red colouring matter }\end{array}$ \\
\hline
\end{tabular}

\section{Method of preparation}

Properly dried stem bark of lodhra is cleaned first to remove foreign matters and then powdered and sieved through $85 \mathrm{mesh}$. exposure to moisture should be avoidedduring preparation of the powder and it should be kept in air-tight container in a dry place. Properly kept powder retains its potency for one year.

For preparing a decotioin for vaginal wash, the stem bark of lodhra is cleaned and coarsely powdered. The decotion is prepared by boiling $20-30 \mathrm{gms}$ of coarse powder of lodhra bark in $300-500 \mathrm{ml}$ of water till 100-125 remains. The decotion is filtered and the liquid thus obtained is used warm for vaginal douche. Fresh decotion should be prepared for the wash every day ${ }^{13}$.

\section{Dosage form}

Grayish brown powder for oral use and decotion for vaginal wash ${ }^{13}$

\section{Therapeutic properties}

lodhra bark has astringent, styptic, anti-inflammatory, and anti microbial properties ${ }^{13}$.

\section{Dose and mode of administration}

Lodhra powder is given orally in the dose of $3-5 \mathrm{gms}$ twice a day with rice water or warm water or honey. Vaginal wash with decotion of lodhra should be done daily for 2-3 weeks till local symptoms are adequately controlled. there after only oral medication should be continued ${ }^{(13)}$

\section{Joint pain}

Ajamodapaper

Composition

\begin{tabular}{|c|c|c|c|c|}
\hline English name & latin name & family & part used & chemical constituent \\
\hline Slender celery, wild selery & Apiumleptophyllum & Apiaceae/umbelliferae & Fruit & Essential oil and fixed oil \\
\hline
\end{tabular}

\section{Method of preparation}

clean the dried fruits of ajamoda by removing the stalks, dust and other foreign matters. grind in a pulverizer or in a mortar and pestle to make a fine powder. filter through a fine sieve of mesh size 85 . store in an air-tight container and consume within one year ${ }^{18}$.

\section{Dosage form}

Aromatic, slightly bitter yellowish-brown powder giving a sensation of warmth to the tongue ${ }^{18}$.

\section{Therapeutic properties}

seeds have antiseptic, diuretic, anti-inflammatory, analgesic, anthelmintic, and anti-spasmodic properties $^{18}$.

\section{Dose and administration}

The dose of the formulation for adults is $1-3 \mathrm{gms}$ and for children $125-500 \mathrm{mg}$, wo or three times a day, with warm water. For local application as poultice, make a paste of the powdered seeds in warm water and apply on the affected joint ${ }^{18}$. 
Jaundice

Katukapowder

Composition

Katuka powder is made from dried rhizomes and roots of the plant for oral use $e^{20}$

\begin{tabular}{|c|c|c|c|c|}
\hline English name & Latin name & Family & Part used & Chemical constituents \\
\hline Picrorhiza, hellebore & $\begin{array}{c}\text { Picrorhizakurroaroyle ex } \\
\text { benth. }\end{array}$ & scrophulariaceae & Rhizome with roots & $\begin{array}{c}\text { Glycosides: picrorhizin and } \\
\text { kutkins }\end{array}$ \\
\hline
\end{tabular}

\section{Method of preparation}

Take 50gms of dried rhizomes of katuka. dry them further to remove moisture for easy powdering. rhizomes should not have been harvested more than one year ago. grind rhizomes in a grinder or pulverizer till fine powder is obtained. filter the powder through mesh size 85 to remove coarse fibers and other particles. keep the powder in a dry and air-tight plastic or glass container and consume it before the next rainy season ${ }^{20}$.

\section{Dosage form}

dusty grey fine powder.

\section{Therapeutic properties}

katuka is bitter tonic with cooling, laxative, carminative, digestive, stomachic, hepato protective, antiviral, anti-pyretic, immuno modulating , free radical scavenging,, anti-spasmodic and anti-inflammatory properties in large doses it acts like purgative ${ }^{20}$.

\section{Dose and mode of administration}

The dose of katuka powder for adults is $1-3 \mathrm{gmsand}$ for children $500 \mathrm{mg}-1 \mathrm{gm}$ to be taken twice daily with water, preferably after meals. consuming the medicine on an empty stomach should be avoided as it may cause nausea and vomiting due to its highly bitter taste ${ }^{.20}$.

\section{Ear ache}

\section{Lashunaoil}

Composition

lashuna oil comprises of lashuna and mustard oil ${ }^{5}$

\begin{tabular}{|c|c|c|c|c|c|}
\hline Name & English name & Latin name & Family & Part used & Chemical constituents \\
\hline lashuna & Garlic & Allium sativumlinn. & Liliaceae & bulb & $\begin{array}{c}\text { Volatile oil containing allyl disulphide, } \\
\text { diallyldisulphide, allin, allicine, } \\
\text { mucilage, albumin }\end{array}$ \\
\hline sarshapa & Mustard & Brassica compestris & Brassicaceae & Seed & $\begin{array}{c}\text { Fixed oils and the glycerides of } \\
\text { palmitic, stearic, oilic linoleic, } \\
\text { linolenic, eicosenoic }\end{array}$ \\
\hline
\end{tabular}

\section{Method of preparation}

Take about $20 \mathrm{ml}$ of mustard oil in vessel and add 5-6 pieces of peeled and slightly crushed fresh garlic cloves. put the mixture on a slow fire for about 5-10min till garlic becomes brown and stop further heating. Filter the mixture through cotton cloth to obtain clear oil and keep it in a clean glass bottle ${ }^{5}$.

\section{Dosage form}

Luke warm, pungent, yellowish -brown oil.

\section{Dose and mode of administration}

Instill medicated oil in the affected ear by tilting the head to opposite side and retain it for about 30 mins by plugging the ear with the cotton swab. repeat the process for other ear if affected. instillation of oil in the ears can be done twice daily for 2-3 days ${ }^{5}$.

\section{Therapeutic properties}

Fresh garlic is anti-inflammatory, anti-fungal, anti-bacterial, anti-viral and anti-helmentic ${ }^{5}$. 
Diarrrhoea

Katujapowder

composition

Katuja powder is prepared from the stem bark of kutaja ${ }^{8}$

\begin{tabular}{|c|c|c|c|c|}
\hline English name & Latin name & Family & Part used & Chemical constituents \\
\hline kulchi , telicherry bark & holarrhenaantidysentericaroxb. & apocynaceae & stem bark & $\begin{array}{c}\text { conessine, } \\
\text { conessemine,kurchicine }\end{array}$ \\
\hline
\end{tabular}

\section{Method of preparation}

Take 50gms of dried stem bark of kutaja and further dry it in the shade to remove moisture for easy powdering. grind stem bark in a grinder or pulverizer till fine powder is obtained. filter the powder through 85mesh to remove coarse particles and fibers. The shelf life of the powder is 4months but it can retain its potency for at least 6months, if kept in an air tight container and protected from direct sunlight and heat ${ }^{8}$.

\section{Dosage form}

Bitter brownish powder ${ }^{8}$.

\section{Therapeutic properties}

The bark of kutaja has anti-diarrohoeal, constipating, astringent, anti-dysenteric, anti-helmentic, carminative and digestive properties ${ }^{8}$.

\section{Dose and mode of administration}

The adult dose of kutaja powder is $3-5 \mathrm{gms}$ for children, $500 \mathrm{mg}-1 \mathrm{gm}$ twice or thrice daily with warm water before meals ${ }^{8}$

\section{CONCLUSION}

Herbs and product containing herbs have been in trade and commerce and are currently used for a variety of purposes. Treatment of herbs by squeezing, steaming, roasting, decocting or infusing in water, extracting with alcohol, or sweetening and baking with honey can create herbal products such as juices, tinctures, decoctions, infusions, gums, fixed oils, essential oils and resins. Herbal medicines are being used by about $80 \%$ of the world population in the developing countries for primary health care. They have stood the test of time for their safety, efficacy, and cultural acceptability and less toxic. The chemical constituents present in herbs are part of the physiological functions of living flora and hence they are believed to have better compatibility with the human body.

\section{REFERENCES}

1. Sharma PC, Yelne MB and Dennis TJ. The Ayurvedic Pharmacopoeia of India. Ministry of Health \& Family Welfare, Department of Indian Systems of Medicine and Homeopathy, New Delhi, India, Reprinted Edition. 2001;I(I):5-6.

2. Database on Medicinal Plants Used in Ayurveda, Central Council for Research in Ayurveda \& Siddha, New Delhi. 2001;3:14.

3. India, Ministry of Health and Family Welfare. The Ayurvedic pharmacopoeia of India. Part I. Vol. III. New Delhi: Department of Indian Systems of Medicine and Homeopathy. 2001;116. National Institute of Science Communication.

4. The useful plants of India. New Delhi: Council of Scientific and Industrial Research. The Wealth of India. 2000.

5. Chatterjee A and Pakrashi SC Raw materials. New Delhi: Public Information Department, Council of Scientific and Industrial Research. The treatise on Indian medicinal plants. 1988.

6. Chatterjee A and Pakrashi SC. The treatise on Indian medicinal plants. New Delhi: National Institute of Science Communication, Council of Scientific and Industrial Research. 1997;5.

7. Kirtikar KR and Basu BD. Database on medicinal plants used in Ayurveda. Vol. 3. New Delhi: Central Council for Research in Ayurveda and Siddha. Indian medicinal plants. Vol. III. Allahabad: LM Basu. 1988. 2005;283.

8. Kurup PNV, Ramadas VNK and Joshi P. Handbook of medicinal plants. New Delhi: Central Council for Research in Ayurveda and Siddha. 1979. 
9. Pharmacological investigations of certain medicinal plants and compound formulations used in Ayurveda and Siddha. New Delhi: Central Council for Research in Ayurveda and Siddha. 1996.

10. Bhattacharjee SK. Handbook of medicinal plants. Jaipur: Pointer Publishers. 1998.

11. Chopra RN, Chopra IC and Varma BS. Supplement to glossary of Indian medicinal plants. New Delhi: Publications and Information Directorate, Council of Scientific and Industrial Research. 1992.

12. Billore KV. Data base on medicinal plants used in Ayurveda. Vol. VI. New Delhi: Central Council for Research in Ayurveda and Siddha. 2004;158.

13. Lavekar GS. Data base on medicinal plants used in Ayurveda. Vol. VIII. New Delhi: Central Council for Research in Ayurveda and Siddha. 2007.

14. Dravyaguna-vijnana. Varanasi: Chaukhamba Sanskrit Bharati Academy, India. Ministry of Health and Family Welfare. 1978;2:313

15. The Ayurvedic formulary of India. New Delhi: Department of Indian Systems of Medicine and Homeopathy. 2000;II.

16. Sharma PC, Yelne MB and Dennis TJ. Charakasamhita commentary. Sootrasthana 25, 40. Varanasi: Chaukhambha Bharati Academy. 2005;468.

17. Database on medicinal plants used in Ayurveda New Delhi: Central Council for Research in Ayurveda and Siddha. 2002;1:447.

18. Tripathi, Studies on mechanism of action of Albizzialebbeck, an Indian indigenous drug in the treatment of atopic allergy. Journal of Ethnopharmacology.

19. Indian Council of Medical Research. Medicinal plants of India. New Delhi: ICMR, 1976. Mitra Roma. Bibliography on pharmcognosy of medicinal plants. Lucknow: National Botanical Research Institute. 1985;1.

20. India, Ministry of Health \& Family Welfare. The Ayurvedic pharmacopoeia of India. Part I. Vol. I. New Delhi: Department of Indian Systems of Medicine and Homeopathy. 2001;5:26,47. 